\title{
Natural regeneration and ecological recovery in Mau Forest complex, Kenya
}

\author{
James Mwangi Kinjanjui ${ }^{1}$, Moses Karachi ${ }^{2^{\star}}$, Kennedy Nyambuti Ondimu ${ }^{3}$ \\ ${ }^{1}$ Department of Resource Survey and Remote Sensing, Nairobi, Kenya \\ ${ }^{2}$ Department of Natural Resources, Egerton University, Egerton, Kenya; ${ }^{*}$ Corresponding Author: karachimoses@yahoo.com \\ ${ }^{3}$ Department of Geography, Egerton University, Egerton, Kenya
}

Received 12 April 2012; revised 1 January 2013; accepted 8 June 2013

Copyright (C) 2013 James Mwangi Kinjanjui et al. This is an open access article distributed under the Creative Commons Attribution License, which permits unrestricted use, distribution, and reproduction in any medium, provided the original work is properly cited.

\begin{abstract}
This study investigated natural ecological recovery in parts of Western and Southwestern blocks of the Mau Forest complex that had experienced varied levels of disturbance. The extent and speed of regeneration in the disturbed regions since the eviction of the setter population were not known. This study thus now provides current baseline data on plant distribution, germination of soil bank seeds, and soil nutrient content. The number of tree species recorded at different levels of disturbance were in increasing order: moderately disturbed (MDF) $>$ undisturbed (UDF) > heavy disturbed forest (HDF). Forest clearing reduced forest basal area and forest stocking of big trees $(\mathrm{dbh} \geq 40 \mathrm{~cm})$ in the HDF by more than 4 and 6 times, respectively, than those in UDF. Tree importance values indicated a reduction in commercially valuable species in HDF. Early colonizers and fire tolerant species were predominant in the HDF whereas non-commercial species dominated MDF. Viable soil seed reserves decreased with soil depth in all forests but content between $0-20 \mathrm{~cm}$ soil depth showed a potential to support regeneration. Total $N$, organic $C$ and available $P$ decreased with increase in forest disturbance. Overall, the disturbed sites showed a general potential for ecological recovery and natural regeneration to UDF status.
\end{abstract}

Keywords: Disturbance; Regeneration; Soil Seed Bank Germination; Nutrients

\section{INTRODUCTION}

The Mau Forest complex is one of the few remaining extensive tracts of natural forest in East Africa. It is a major species-rich forest conservation area for wild species. It holds at least 61 tree species including four genera endemic to the region (Sychotria, Eugenia, Rimora and Premna), 80 climbers and shrubs [1] and four rare endangered animal species (golden cat (Profelis aurata), forest hog (Hylochoerus meinertzhageni), bongo (Tragelaphus eurycerus) and yellow backed duiker (Cephalophus silvicutor). It is one of the major and also crucially important water catchment areas in Kenya. The forest complex is the traditional home for the Okiek community whose livelihood largely depended on the forest [2]. This community had a culture of protecting the forest resources. However, with the increased population and demand for forest products, they shifted into small scale mixed farming activities. There was also an influx into the forest of farming communities adjacent to the forest. These communities used fire to clear land for cultivation which resulted in large expanses of fire maintained ecosystems in the forest. In addition, more than 250,000 households comprised of small scale farmers within a 5 $\mathrm{km}$ distance from the forest boundary exerted considerable pressure on forest resources [3].

In view of the forests ecological characteristics and the need to conserve this vital habitat, genetic resource and water catchment, evictions and resettlements of forest residents started in 1940's and completed in 2003. This study investigated recovery of the forest after human encroachment. Such information is crucial for future ecological monitoring and understanding the dynamics of ecological recovery in this forest ecosystem. The objective was to determine species diversity, tree species distribution and regeneration, soil seed germination and soil nutrient status as indicators of ecological recovery. These parameters were examined in the heavy disturbed forest (HDF), moderately disturbed forest (MDF) and compared to those of undisturbed forest (UDF). 


\section{MATERIALS AND METHODS}

\subsection{Site}

The study was conducted in Western and Southwestern blocks of Mau forest complex (Latitude $0^{\circ} 15^{\prime} \mathrm{S}-0^{\circ} 47^{\prime} \mathrm{S}$ Longitude $35^{\circ} 28^{\prime} \mathrm{E}-35^{\circ} 69^{\prime} \mathrm{E}$ ) has an extremely rugged terrain. The forest was classified as afromontane mixed forest [4] while [5] used the dominant tree species to delineate three forest formations: 1) Aningera adolfifriedirici/Drypetes gerrardii, 2) Albizia gummifera/Neuboutonia macrocalyx and 3) Polyscias fulva/Podocarpus latifoluius formations occurring at $1600-2100 \mathrm{~m}, 1650$ $2250 \mathrm{~m}$ and 1650 - $2800 \mathrm{~m}$ a.s.l, respectively. However, these formations are constantly overlapped. Rainfall is bimodal with peaks in April and August and ranges from 2000 - $3000 \mathrm{~mm}$ per annum. Mean annual temperatures range from a minimum of $16^{\circ} \mathrm{C}$ in July to a maximum of $22^{\circ} \mathrm{C}$ in September. Soils are mainly mollic andosols derived from tertially volcanic parent material. The HDF (34,000 ha) had been converted into agricultural farms through slashing and burning and by setting fires to improve pastures whereas the MDF (62,000 ha) bordered small scale farms. Plantation forests formed a buffer zone between the small scale farms and the MDF. However, the good road network enabled continued exploitation of commercially viable trees in the natural forests. The remaining small UDF (10,000 ha) in pristine conditions is protected by extensive tea estates.

\subsection{Data Collection}

Because of ease of accessibility, all data was collected at altitude range of $2100-2700 \mathrm{~m}$ a.s.1.

\subsection{Vegetation}

Using E-trex model GPS receiver, 2, 4 and 3 starting positions were located on the edge of the HDF, MDF and UDF, respectively, then glid lines running in east-west direction were drawn on topographical maps. On the ground, sample plots ( $28 \mathrm{~m}$ radius) were allocated proportional to the heterogeneity in sample sites. Six, 19 and 25 sample plots were established starting $200 \mathrm{~m}$ from the edge of the forest and at least $1 \mathrm{~km}$ apart in the HDF, MDF and UDF, respectively. Within each plot, nested quadrats were established for assessment of abundance of different diameter size-classes of tree species.

Trees $(\geq 10 \mathrm{~cm} \mathrm{dbh})$ and poles $(5-9.9 \mathrm{~cm} \mathrm{dbh})$ were enumerated in the whole plot while saplings $(2.5-4.9$ $\mathrm{cm} \mathrm{dbh})$ and seedlings $(<2.5 \mathrm{~cm} \mathrm{dbh})$ were enumerated in $7 \mathrm{~m}$ and $3.5 \mathrm{~m}$ radius circles respectively in the middle of the plot. These data was used to plot the forest structure curves [6], calculate importance values, forest basal area and species diversity [7]. The total numbers of each species found in the sites were counted, then ranked in decreasing order based on the totals enumerated. The species rankings from the disturbed sites were subsequently compared with rankings in the UDF using chisquare test. The chi-test procedure was also used to compare tree size regeneration classes.

\subsection{Soil Seed Germination}

Each forest type was roughly divided into four quarters and a $50 \mathrm{~cm}^{2}$ plot randomly marked in each portion. The herbaceous vegetation layer was carefully removed with minimal interference with the litter and mineral surface layers. Subsequently, soil layers $(0-10 \mathrm{~cm}, 10$ $20 \mathrm{~cm}$ and $20-30 \mathrm{~cm}$ depths) were dug separately, put into a polythene bag and taken to the greenhouse. The soil was spread thinly on a germination bed and watered daily. Germination was recorded from start of germination at 7-day intervals for 140 days. Seedlings were identified by species, recorded, then uprooted. Sorenson's coefficient of similarity [8] was used to estimate the degree of similarity of the regenerating species.

\subsection{Soil Nutrient Analysis}

A soil core (0 - $30 \mathrm{~cm}$ depth) was dug using a $15 \mathrm{~cm}$ diameter auger adjacent to the plots used for seed viability trial. These cores were partitioned into $0-10 \mathrm{~cm}, 10-$ $20 \mathrm{~cm}$ and $20-30 \mathrm{~cm}$ soil depths then composited, debris was removed and soils thoroughly mixed. Another six soil cores were also dug at random from an adjacent agricultural farm, then soil was treated as above. Six subsamples from each soil depth were subjected to chemical analysis [9]. The nutrient concentrations data was subjected to analysis of variance.

\section{RESULTS}

\subsection{Forest Composition}

Fifty indigenous tree species were identified in total; 38,49 and 46 in the HDF, MDF and UDF, respectively. Neoboutonia macrocalyx, an early colonizer in disturbed sites in this forest, was ranked as the most abundant in the HDF. The other highly ranked species included Croton macrostachyus, Euphorbia candelabrum and Elaeodendron buchananii that are fire tolerant. Trees with low commercial value; Polyscias fluva, E. Candelabrum and Syzgium guineense were the highest ranked in the MDF. Comparison of rankings of the ten dominant species in the UDF to rankings in the other disturbance levels is shown in Table 1. There was a decline in ranking of several species in the disturbed forests. Albizia gummifera and Drypetes gerradii were absent in the HDF. Forest degradation also reduced forest stocking of big trees $(\geq 40 \mathrm{~cm} \mathrm{dbh})$ from 70,57 and 11 stems ha $^{-1}$ in the UDF, MDF and HDF, respectively. Similarly, the 
Table 1. Differences in ranking of the dominant trees among disturbance levels.

\begin{tabular}{cccc}
\hline \multirow{2}{*}{ Tree species } & \multicolumn{3}{c}{ Ranking } \\
\cline { 2 - 4 } & UDF & MDF & HDF \\
\hline Tabernamontana stapfiana & 1 & $12^{*}$ & 3 \\
Allophyllus abyssinica & 2 & $32^{*}$ & $20^{*}$ \\
Macaranga kilimandischarica & 3 & 5 & 4 \\
Syzigium guineense & 4 & 4 & $27^{*}$ \\
Albizzia gummifera & 5 & $11^{*}$ & absent $^{*}$ \\
Polysias fulva & 6 & 1 & $21^{*}$ \\
Euphhorbia candelabrum & 7 & 2 & 9 \\
Podocarpus latifolius & 8 & 10 & 3 \\
Aningera adolfi-friedirici & 9 & $15^{*}$ & 6 \\
Drypetes gerrardii & 10 & $20^{*}$ & absent $^{*}$ \\
\hline
\end{tabular}

"Significant decrease in ranking $(\mathrm{P}<0.05)$.

forest basal area for this category of trees decreased with the level of forest degradation from 36.1, 27.9 and 7.8 $\mathrm{m}^{2} \cdot \mathrm{ha}^{-1}$, in the UDF, MDF and HDF, respectively.

\subsection{Tree Regeneration}

Seedlings and saplings were at least 1.8 times as abundant in the HDF than in UDF, implying that recruitment into saplings in the HDF was higher that than in UDF. However, poles and trees were greater than 3 times more frequent in the UDF than in HDF (Table 2). The tree populations in the MDF were intermediate. Tree sizeclass distribution generated "inverted J" curves for the HDF and MDF that were above the UDF curve for size classes $<2.5 \mathrm{~cm}$ and $2.5 \mathrm{~cm}-4.9 \mathrm{~cm}$ dbh regeneration. The disturbed forest areas contained plants in smaller size classes than the UDF (Figure 1). Calculated Shannon-Weiner diversity indices for all disturbance levels decreased from 2.2 in all disturbance levels to 1.5 (HDF and MDF) and 1.6 (UDF) for trees $\mathrm{dbh} \geq 40 \mathrm{~cm}$ indicating that there was less diversity for mature trees.

\subsection{Soil Seed Germination}

There was a progressive decline in the number of regenerative species which reflected the levels of forest disturbance. Seeds of 20, 23 and 28 species germinated from soil collected in the HDF, MDF and UDF, respectively. Similarly, there was dissimilarity in the member of species that germinated. Emerging seedlings had the following Sorenson's similarity indices; HDF vs MDF = $0.797, \mathrm{HDF}$ vs $\mathrm{UDF}=0.545$ and $\mathrm{MDF}$ vs $\mathrm{UDF}=0.877$. Neuboutonia macrocalyx showed the highest regeneration capacity in all forest types. Overall, 257, 177 and
Table 2. Tree size-class distribution.

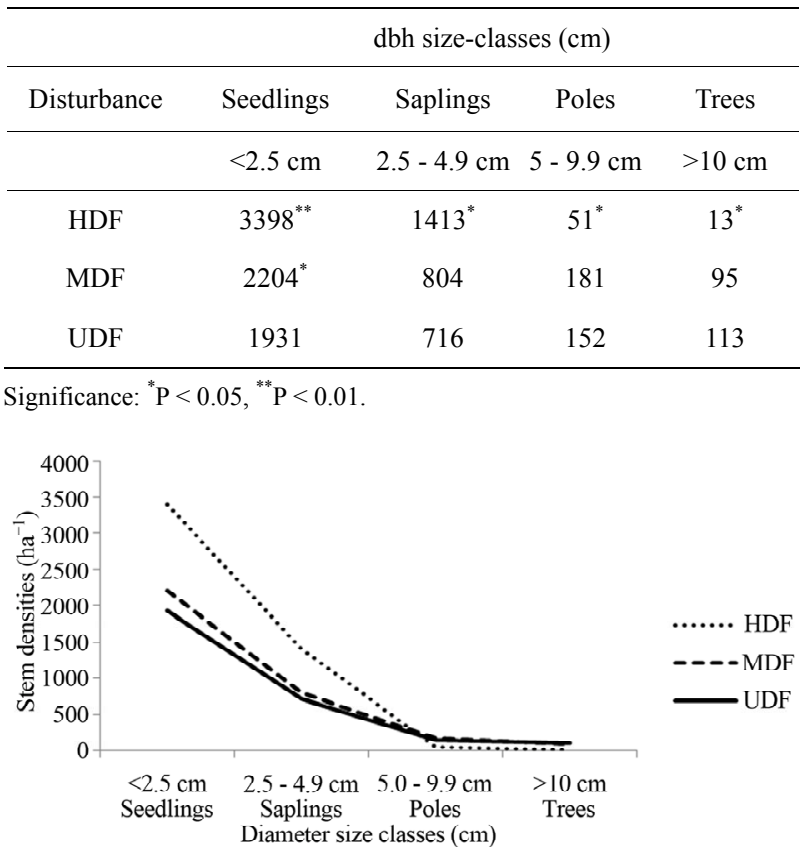

Figure 1. Tree demographic patterns in the heavy disturbed, moderately disturbed and undisturbed forests.

159 seeds germinated from HDF, MDF and UDF soils, respectively. In addition, seed germination was highest from seeds found within $0-10 \mathrm{~cm}$ soil depth and the number of germinating seeds decreased with increase in soil depth; germination was only recorded for seeds from the UDF at $\geq 20 \mathrm{~cm}$ soil depth (Figure 2).

\subsection{Soil Chemical Parameters}

Conversion of forest land to agricultural production and forest degradation resulted in the reduction of soil $\mathrm{pH}$, total $\mathrm{N}$, organic $\mathrm{C}$ and available $\mathrm{P}$ (Table 3 ). The levels of these nutrients also decreased with increase in soil depth. The concentrations of $\mathrm{K}, \mathrm{Ca}, \mathrm{Mg}$ and $\mathrm{Na}$ were not influenced by land use.

\section{DISCUSSION}

Human-induced forest degradation resulted in reduction of species diversity and decrease in some soil nutrient contents. The HDF consisted of open forests in various re-growth stages. Since this section had an open canopy, few seedlings of primary trees were recorded similar to the observations by Bazzaz [10]. It was dominated by light demanding, early succession species as typical of open habitats [11]. The highest ranked, Neoboutonia Macrocalyx, is fast growing and adaptable to poor site conditions and is often the first woody species in succession to a mature forest after a disturbance in this forest $[5,12]$. This species would be a good can- 


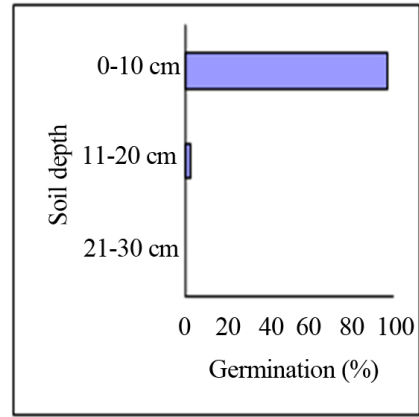

Heavy disturbed

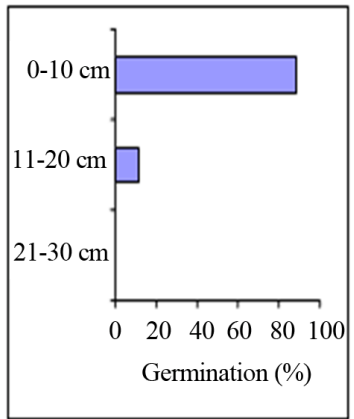

Moderate diaturbed

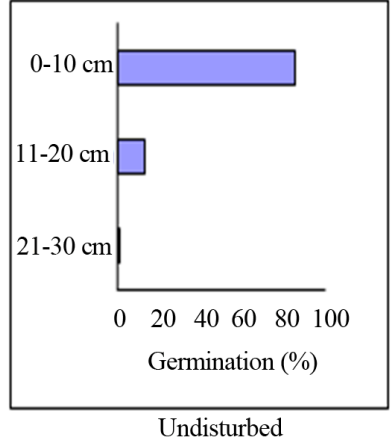

Figure 2. Effect of soil depth on seed germination from different forest types.

Table 3. Effect of forest disturbance on soil nutrient concentrations at different soil depths.

\begin{tabular}{|c|c|c|c|c|c|c|c|c|c|c|}
\hline \multirow{2}{*}{$\begin{array}{l}\text { Soil depth } \\
\text { (cm) }\end{array}$} & \multirow{2}{*}{ Disturbance } & \multirow{2}{*}{$\mathrm{Ph}$} & \multirow{2}{*}{ Total N (\%) } & \multirow{2}{*}{ Org C (\%) } & \multirow{2}{*}{ Avail. P (ppm) } & \multicolumn{5}{|c|}{$\mathrm{Me} / 100 \mathrm{~g}$ soil } \\
\hline & & & & & & $\mathrm{K}$ & $\mathrm{Ca}$ & $\mathrm{Mg}$ & $\mathrm{Mn}$ & $\mathrm{Na}$ \\
\hline \multirow[t]{4}{*}{$0-10$} & Farm & $5.2^{\mathrm{a}}$ & $0.5^{\mathrm{a}}$ & $4.9^{\mathrm{a}}$ & $6^{\mathrm{a}}$ & 1.4 & 4.8 & 3.2 & 1.2 & 0.2 \\
\hline & $\mathrm{HDF}$ & $6.1^{\mathrm{b}}$ & $0.4^{\mathrm{a}}$ & $4.0^{\mathrm{a}}$ & $7^{\mathrm{a}}$ & 1.2 & 4.7 & 3.2 & 1.2 & 0.2 \\
\hline & MDF & $6.2^{\mathrm{b}}$ & $1.0^{\mathrm{b}}$ & $6.4^{\mathrm{b}}$ & $11^{\mathrm{b}}$ & 1.5 & 5.2 & 5.3 & 1.2 & 0.3 \\
\hline & UDF & $6.2^{\mathrm{b}}$ & $1.2^{\mathrm{b}}$ & $6.6^{\mathrm{b}}$ & $18^{\mathrm{b}}$ & 1.6 & 5.4 & 5.4 & 1.3 & 0.2 \\
\hline \multirow[t]{4}{*}{$11-20$} & Farm & $5.2^{\mathrm{a}}$ & $0.5^{\mathrm{a}}$ & $4.9^{\mathrm{a}}$ & $6^{\mathrm{a}}$ & 1.4 & 4.6 & 4.0 & 1.2 & 0.2 \\
\hline & $\mathrm{HDF}$ & $6.1^{\mathrm{b}}$ & $0.4^{\mathrm{a}}$ & $4.3^{\mathrm{a}}$ & $6^{\mathrm{a}}$ & 1.4 & 4.8 & 3.6 & 1.2 & 0.2 \\
\hline & MDF & $6.1^{\mathrm{b}}$ & $1.0^{\mathrm{b}}$ & $6.1^{\mathrm{b}}$ & $11^{\mathrm{b}}$ & 1.5 & 4.9 & 5.2 & 1.2 & 0.2 \\
\hline & UDF & $6.1^{\mathrm{b}}$ & $1.2^{\mathrm{b}}$ & $6.3^{\mathrm{b}}$ & $17^{\mathrm{b}}$ & 1.6 & 5.3 & 5.2 & 1.2 & 0.2 \\
\hline \multirow[t]{4}{*}{$21-30$} & Farm & $5.2^{\mathrm{a}}$ & $0.5^{\mathrm{a}}$ & $5.0^{\mathrm{a}}$ & $7^{\mathrm{a}}$ & 1.4 & 4.7 & 4.2 & 1.2 & 0.2 \\
\hline & $\mathrm{HDF}$ & $6.1^{\mathrm{b}}$ & $0.4^{\mathrm{a}}$ & $4.5^{\mathrm{a}}$ & $6^{\mathrm{a}}$ & 1.4 & 4.9 & 3.5 & 1.2 & 0.2 \\
\hline & MDF & $6.1^{\mathrm{b}}$ & $0.9^{\mathrm{c}}$ & $6.2^{\mathrm{b}}$ & $11^{\mathrm{b}}$ & 1.5 & 4.8 & 5.3 & 1.2 & 0.2 \\
\hline & UDF & $6.4^{\mathrm{b}}$ & $1.0^{\mathrm{c}}$ & $6.3^{\mathrm{b}}$ & $17^{\mathrm{b}}$ & 1.6 & 5.1 & 5.4 & 1.2 & 0.2 \\
\hline
\end{tabular}

${ }^{a, b}$ Mean in a column within a soil depth followed by different superscripts differ $(\mathrm{P}<0.05)$.

didate in forest recovery programmes in the area. Consistent use of fire may also have adversely affected the seeds and vegetative propagules of some species. To the extent, they lost the ability to germinate and succeed in the degraded forest over time [13]. The primary species are likely to be affected because their seeds germinate quickly after dispersal and generally exhibit a short dormancy period [11]. Absence of species like Albizzia gummifera and Drypetes. Gerradii in the HDF was an indication of reduced species richness associated with forest degradation. These species were described as common trees in this forest [5]. Other dominant species like Euphhorbia Candelabrum and Elaeodendron buchananii are fire tolerant, one of the methods used to clear the forest. Trees of high commercial value such as Podocarpus. latifolius and Olea capensis were lowly ranked in the MDF reflecting effects of selective harvesting.
Juniperus procera which is widely used for construction poles [14] was ranked high in this forest because its regeneration is favoured by moderate opening of the forest canopy [15].

A high seedling and sapling population in the HDF and MDF is typical where recent disturbances create favourable conditions for regeneration [16] and is consistent with intermediate hypothesis [17]. Regeneration potentially generated "inverted J" size-class distribution curves. The curve for the UDF is typical of mature stable systems [18]. As expected in natural forests [7], tree diversity decreased with increase in tree size-class. The few species with $\mathrm{dbh} \geq 10 \mathrm{~cm}$ in the HDF reflects incomplete recovery from degradation. The forest basal area $\left(7.8 \mathrm{~m}^{2} \cdot \mathrm{ha}^{-1}\right)$ was also well below the minimum (30 $\mathrm{m}^{2} \cdot \mathrm{ha}^{-1}$ ) for a well stocked forest [19].

The soil seeds that germinated indicated reduced spe- 
cies richness in the disturbed sites. The seed distribution pattern in the soil agrees with several other reports [20,21]. Seeds buried deep into the soil were not viable in agreement with other authors [22,23]. This has been attributed to seed aging and subsequent loss in viability. The results indicate that environmental modification of the top soil layer could adversely influence seedling population.

Since soils were similar, any change between the disturbance levels with respect to soil nutrient contents was probably due to effect of human activities on forest degradation. The HDF soil had low $\mathrm{pH}$, total $\mathrm{N}$, organic $\mathrm{C}$ and available $\mathrm{P}$, similar to those of the soil from the agricultural farm. Loss of organic matter by water erosion and accelerated oxidation probably accounted for the low soil nutrient levels [24]. Greater nutrient concentrations in the UDF and MDF soils may be due to higher litterfall deposition and efficient litter decomposition mechanisms [25]. The decrease in nutrient concentrations with soil depth was most marked in $0-10 \mathrm{~cm}$ layer in agreement with Rhodes [26] in that processes that influence nutrient fluxes in forest soils are most felt in the top soil. Anthropogenic activities that would removed this soil layer, which also contained most of the seed bank, may have been responsible for overall decrease in soil nutrients and species diversity in disturbed sites. Similarly, as available $\mathrm{P}$ is critical in recruitment and growth of forest species [27], the low levels in the HDF was probably a factor contributing to reduced establishment of primary forest seedlings.

The time period of the study was too short for the soils in the HDF to have recovered UDF nutrient status. However, since the HDF had many of the species found in the UDF, soil factors may not be the only factors limiting its regeneration. Light intensity, canopy openness, suppression by grasses of the young tree seedlings, etc. may account for the differences between the habitats. Overall, presence of soil seeds of many species with potential germination indicates that forest re-establishment can be achieved in the HDF if sufficient undisturbed period is allowed.

\section{REFERENCES}

[1] Beentje, H.J. (1990) The forests of Kenya. Proceedings of $12^{\text {th }}$ Plenary Meeting of Aetfat, Hamburg, 23, 265-286.

[2] Kenya Indigenous Forest Conservation (1993) Mau forest conservation project proposal. KFCON Report, Vol. 4, Nairobi.

[3] Minisrty of Finance and Plannimg (2000) Poverty in Kenya. Incidence and Depth of Poverty in Kenya, Vol. 6, Nairobi.

[4] White, F. (1983) The vegetation of Africa. UNESCO, Paris.

[5] Mutanga, J.G., Mwangangi, O.M. and Mwaura, P.K. (1993)
Mau forest complex vegetation survey. KIFCON Report, Nairobi.

[6] Alder, D. and Synnott, T.J. (1992) Permanent sample plot techniques for mixed tropical forest. Oxford Forestry Instatute, Tropical Forest Papers, 25.

[7] Magurran, A.E. (1988) Ecological diversity and its measurement. Chapman and Hall, London. http://dx.doi.org/10.1007/978-94-015-7358-0

[8] Kent, M. and Coker, P. (1992) Vegetation description and analysis. John Wiley and Sons, New York.

[9] Okalebo, J.R., Gathna, K.W. and Woomer, P.L. (1993) Laboratory methods of soil and plant analysis. A working manual. Tropical Soil Biology and Fertility, UNESCOROSTA.

[10] Bazzaz, E.A. (1991) Regeneration of tropical forests. Physiological responses of secondary species. In: GomezPompa, A., Whitmore, T.C. and Halley, M., Eds., Rain Forest Regeneration and Management, Parthenon Publishing Group and UNESCO, Paris, 91-118.

[11] Whitmore, T.C. (1991) Tropical rain forest dynamics and its implications for management. In: Gomez-Pompa, A., Whitmore, T.C. and Halley, M., Eds., Rain Forest Regeneration and Management, Parthenon Publishing Group and UNESCO, Paris, 67-90.

[12] Beentje, H.J. (1994) Kenya trees, shrubs and lianas. National Museums of Kenya, Nairobi.

[13] Uhl, C., Clark, K., Clark, H. and Murphy, P. (1981) Early plant succession after cutting and burning in the upper Rio Negro region of the Amazon Basin. Journal of Ecology, 69, 631-649. http://dx.doi.org/10.2307/2259689

[14] Jama, M. (1991) Forest utilization by people living adjacent to West Mau, Southwestern Mau and Transmara Forest Reserves. KIFCON Report, Nairobi.

[15] Pohjonen, V.M. (1991) Volume equations and volume tables of Juniferus procera in Ethiopia. Forest Ecology and Management, 44, 185-200.

[16] Mouphalu, J.I. (2006) Tree species population dynamics in a secondary forest at Ile-Ife, Nigeria after a ground fire. African Journal of Ecology, 45, 62-71.

[17] Connell, J.H. (1978) Diversity in tropical rainforests and coral reefs. Science, 199, 1302-1310. http://dx.doi.org/10.1126/science.199.4335.1302

[18] Changui, P. (2000) Growth and yield models for uneven-aged stands: Past, present and future. Forest Ecology and Management, 132, 259-279. http://dx.doi.org/10.1016/S0378-1127(99)00229-7

[19] Korgaard, S. (1992) An analysis of growth parameters and timber yield prediction based on research plots in the permanent forest estate Sarawak, Malaysia. The Council for Development Research, Copenhagen.

[20] Valbuena, I. and Trabad, L. (2001) Contribution of soil seedbank to post fire recovery of a heathland. Plant Ecology, 152, 175-183. http://dx.doi.org/10.1023/A:1011419721307

[21] Osumi, K. and Sakurai, S. (1997) The seedling emergence of Betula maximowiczianz following human disturbances and the role of buried seeds. Forest Ecology 
and Management, 93, 235-243.

http://dx.doi.org/10.1016/S0378-1127(96)03963-1

[22] Karachi, M., Giathi, G. and Muchiri, N.M. (2006) Factors influencing the natural regeneration of Polyscias kikuyensis (Summeerh) in Nyamweru forest-Kikuyu escarpment, Kenya. African Journal of Ecology, 45, 242-248. http://dx.doi.org/10.1111/j.1365-2028.2006.00698.x

[23] Mcgee, A. and Feller, M.C. (1993) Seed banks of the forested and disturbed soils in the Southwestern British Colombia. Canadian Journal of Botany, 71, 1574-1583. http://dx.doi.org/10.1139/b93-192

[24] Dagar, J.C., Mongia, A.D. and Singh, N.T. (1995) Degradation of tropical rain forest soils upon replacement with plantation and arable crops in Andaman and Nicobar. Tropical Ecology, 56, 89-101.

[25] Islam, K.R. and Well, R.R. (2000) Land-use effects on soil quality in a tropical forest ecosystem of Bangladesh. Agriculture Ecosystems and Environment, 79, 9-16. http://dx.doi.org/10.1016/S0167-8809(99)00145-0

[26] Rhodes, C.C. (1997) Single tree influences on soil properties in agroforestry: Lessons from natural forest and savanna ecosystems. Agroforestry Systems, 35, 71-94. http://dx.doi.org/10.1007/BF02345330

[27] Federer, C.A., Hornbeck, J.W., Triton, L.M., Martin, C. W., Pierce, R.S. and Smith, C.T. (1989) Long-term depletion of calcium and other nutrients in Eastern US forests. Environmental Management, 13, 593-601. http://dx.doi.org/10.1007/BF01874965 